\title{
The Soft Story Challenge to Architectural Design in Earthquake-Prone Areas
}

\author{
Livian Teddy* \& Gagoek Hardiman \\ Doctoral Program of Architecture and Urbanism, Diponegoro University, Semarang, Indonesia \\ Nuroji \& Sri Tudjono \\ Doctoral Program of Civil Engineering, Diponegoro University, Semarang, Indonesia
}

\begin{abstract}
The stiffness of irregular configurations/soft storeys is the most frequent cause of structural failure in the irregular vertical part of a building when major earthquakes occur in Indonesia, leaving behind many victims. Soft storeys occur because the first floor of a building is usually more flexible than the other floors. When a strong earthquake occurs, the more flexible storey is not strong enough to withstand the force of the earthquake, and it will cause the building to break and collapse. This paper attempted to address the structural failure of the soft storey, particularly in Indonesia, with regard to its causes, and to find ways to evaluate it and to overcome it through architectural designs. Therefore, this can be taken into consideration by architects in their designing process. The research involved a literature review of topics on soft storeys from existing books and researches. Based on the study, the occurrence of soft storeys in Indonesia is due to inadequate shear column capacity, the presence of a weak storey, a significant difference in wall densities between the floors, the use of materials with different degrees of stiffness in the main structure, structural ductility and poor construction. To reduce the potency of soft storeys, several things can be done by architects in their designing processes such as avoiding direct contact between brick walls, columns and beams, increasing the shear capacity of columns by 2.5 times the normal calculation, using shear walls on the first floor, installing bracings and using seismic insulations
\end{abstract}

Keywords: Soft story; stiffness irregularity configuration; weak story

ABSTRAK

Konfigurasi kekakuan tidakteratur/lantai lembut adalah bahagian menegak - tidak teratur dan merupakan kegagalan struktur yang paling kerap apabila gempa bumi besar berlaku di Indonesia dan menyebabkan banyak mangsa. Lantai lembut ini disebabkan oleh lantai pertama sebuah bangunan yang lebih fleksibel daripada lantai lain. Dalam kes gempa bumi yang kuat, lantai yang lebih fleksibel tidak cukup kuat untuk bertahan dan menjadikan bangunan menjadi rosak dan runtuh. Kertas kerja ini cuba mengatasi kegagalan struktur lantai lembut, terutama di Indonesia yang dilacak dari sebabsebabnya, mencari jalan untuk menilainya, dan mencari jalan untuk mengatasinya dalam reka bentuk seni bina. Oleh itu, kajian ini boleh dikira oleh arkitek dalam proses reka bentuk yang mereka lakukan. Kajian yang dijalankan dalam kertas kerja ini adalah semakan kajian mengenai topik lantai lembut yang diperoleh dari buku dan hasil penyelidikan yang ada. Berdasarkan kajian ini, lantai lembut yang berlaku di Indonesia disebabkan oleh: kapasiti lajur ricih yang tidak mencukupi, adanya lantai yang lemah, perbezaan ketara dalam kepadatan dinding antara lantai, penggunaan bahan yang mempunyai kekakuan yang berbeza dalam struktur utama, dan struktur kemuluran dan pembinaan yang lemah. Untuk mengurangkan potensi lantai yang lembut, beberapa perkara boleh dilakukan oleh arkitek dalam merancang proses seperti: mengelakkan hubungan langsung antara dinding bata dengan lajur dan balok, meningkatkan kapasiti lajur ricih hingga 2.5 kali perhitungan normal, dengan menggunakan dinding ricih di tingkat pertame, memasang penahan, dan menggunakan penebat seismik.

Kata kunci: Lantai lembut; konfigurasi kekakuan tidak teratur; lantai lemah

\section{INTRODUCTION}

Indonesia is an area prone to earthquake or ring of fire. There have been many major and minor earthquakes occurring in all parts of this country from Sabang to Merauke. The last major earthquake was the Aceh earthquake in 2004 which triggered Tsunami that caused tremendous loss not only it took many lives but also it badly damaged infrastructures such as roads, seaports, houses, buildings, and other facilities (Rashid 2016).
Based on the earthquake occurrences, only from 1980 to 2000 and according to a UN report in 2004 (Pelling et al. 2004), Indonesia is the second most vulnerable country after Japan and is the country whose population (in millions) suffers most from earthquakes (see Figure 1).

The biggest casualties were not caused by the earthquake directly, but due to the collapse of the buildings. Since Indonesia is located in an earthquake-prone zone, the 


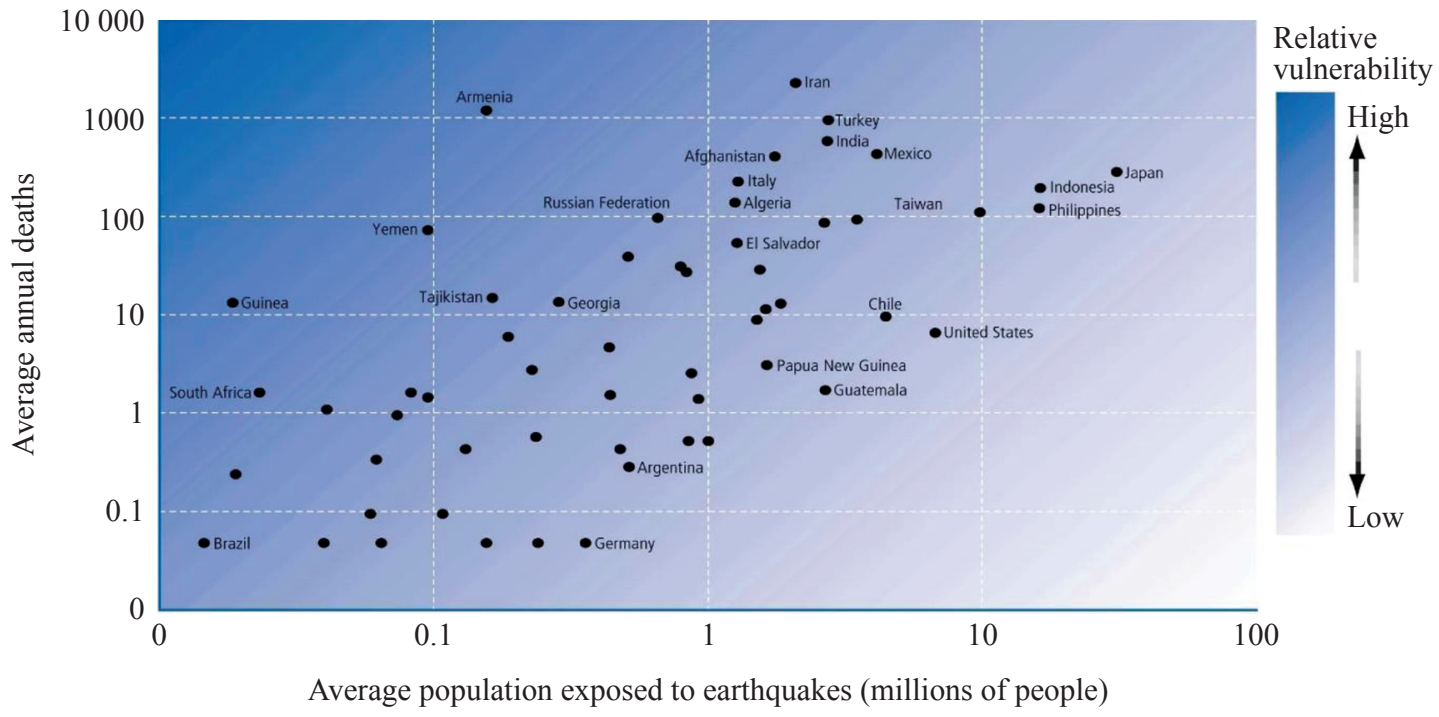

FIGURE 1. The relative vulnerability of earthquakes in 1980 to 2000 (source: Pelling et al. 2004)

buildings in this country should be designed to resist earthquakes.

The fact that a building damage type repeats in every major earthquake indicates that there are malpractices in construction (Hoedajanto and Riyansyah 2015). The fatal building damage due to earthquakes in Indonesia occurred not only in 'non-engineered' buildings but also in 'engineered' buildings (Boen 2006, 2007a, 2007b), and this condition should not happen. With formal knowledge about buildings, the fatal damage to the engineered buildings should be minimized. Based on Boen's research (Boen 2006, 2007a, $2007 \mathrm{~b}$ ), the most frequent structural failure that happened during big earthquakes in Indonesia involved the soft story. According to Arnold (2001) the soft story is a significant decrease of a building story's lateral stiffness compared to story above it. In other words, the soft story results from a more flexible building level compared to other building levels. When there is a strong earthquake, the more flexible story is more susceptible to cyclic seismic shake, and when the shake exceeds the shear strength of the column, it may break and cause the building to collapse (Figure 2). Soft story is one of the most dangerous geometry configuration types of building irregularity (Mezzi 2006).

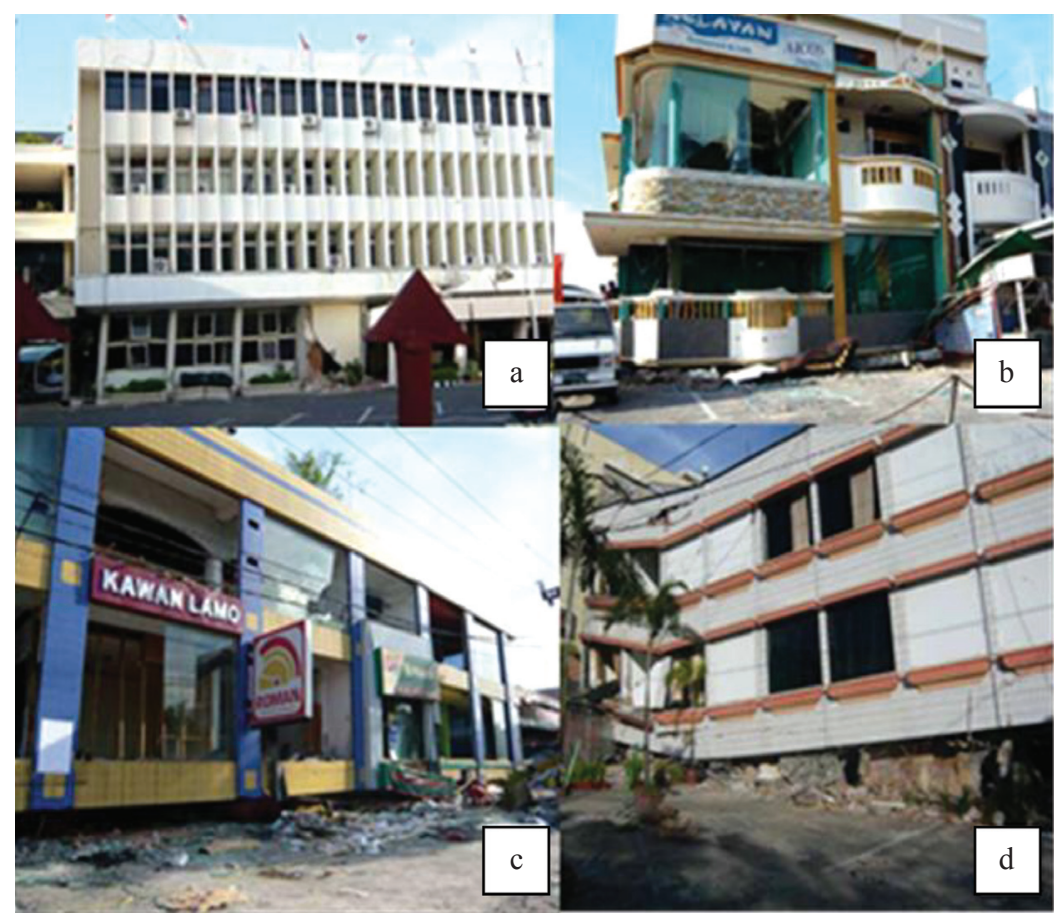

FIGURE 2. The Padang earthquake on September 30 \& October 1, 2007: a). The Office of DPU Padang experienced a soft story on the $1^{\text {st }}$ floor but it was still survived, b). The shophouse 3 stories experienced severe a soft story at the $1^{\text {st }}$ floor. This floor collapsed, and the $2^{\text {nd }}$ $\& 3^{\text {th }}$ floors fell on it, c). $\&$ d). The commercial building experiencing a severe soft story at the $1^{\text {st }}$ floor. This floor collapsed, and the $2^{\text {nd }}$ $\& 3^{\text {th }}$ floors fell on it (source: http://www.perencanaanstruktur.com/2010/10/bentuk-keruntuhan-bangunan-saat-gempa.html). 
This paper analyses the causes of structural failure due to the soft story at buildings in Indonesia and offers suggestions to overcome it with architectural design. Therefore, architects can use the information provided in this paper when designing earthquake-resistant buildings to minimize the potential soft story of buildings in earthquake prone areas especially in Indonesia.

\section{RESEARCH METHODS}

The research done in this paper was a literature review research on soft story topics from existing books and researches. The content of this paper is divided into three parts. The first part is factors causing the soft story and a case study; the second part is an evaluation of the soft story configuration on the building; and the third part is the concept of the soft story configuration solution in buildings.

\section{THE SOFT STORY}

(Federal Emergency Management Agency-FEMA USA) FEMA 451B (FEMA 2007) mentions that there are 10 geometric configurations that reduce building resistance to earthquakes. The five categories are the horizontal irregularities namely torsional irregularity, re-entrant corner irregularity, diaphragm discontinuity irregularity, out of plane offsets irregularity, and nonparallel system irregularity while the other five categories, the vertical irregularities, are stiffness (soft story) irregularity, weight (mass) irregularity, vertical geometry irregularity, in-plane discontinuity irregularity, and strength (weak story) irregularity. The soft story is included as the vertical irregularities category namely the vertical stiffness irregularity. Definitively this irregularity happens if the lateral stiffness of a building level is less than 70 percent compared to levels above it or less than 80 percent compared to three levels above it. The key word is the relative difference in building stiffness.

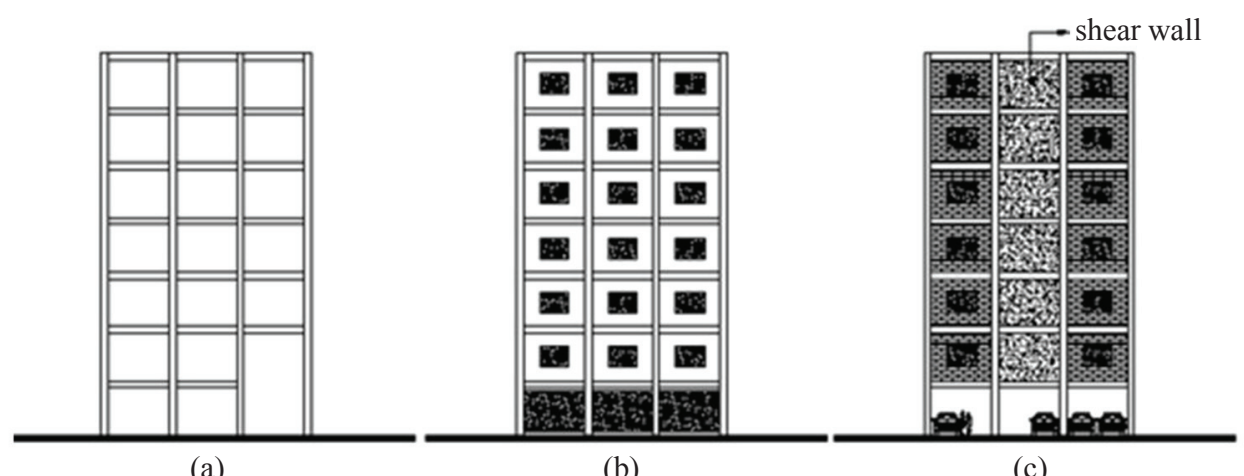

FIGURE 3. a). Some of the first stories become banking halls having height 2 stories, b). The first stories use transparent walls, and the second \& third stories use massive walls, c). The first stories are open for parking and for shear wall continuing from the top story but disconnected at the first story.

Several factors that cause soft stories (Arnold 2001) are: (1). The first story's structure columns are higher than the upper stories' structure columns resulting in less stiffness and greater deformation on the first story. The first story is higher than the stories above it because it usually accommodates a large space such as a meeting room, banking hall, etc. (see Figure 3a), (2). There is a sudden change of stiffness on the second story although the height between stories is relatively the same, and this is typically mainly due to the selection of wall materials; for example, the first story, for an an open impression, usually uses transparent materials such as glass that is left stiff; or if it is used as a parking lot, it is left open and the upper stories use relatively stiff wall materials such as brick walls (see Figures $3 b$ \& 3c), (3). There are shear wall discontinuities where the shear force is held by walls that are not continuous to the foundation but end only on the second story which cause sudden stiffness change (see Figure 3c).

Soft stories often occur on the first floor, but they may also occur at any floor provided the stiffness of a floor is the weakest compared to other floors (Figure 4).

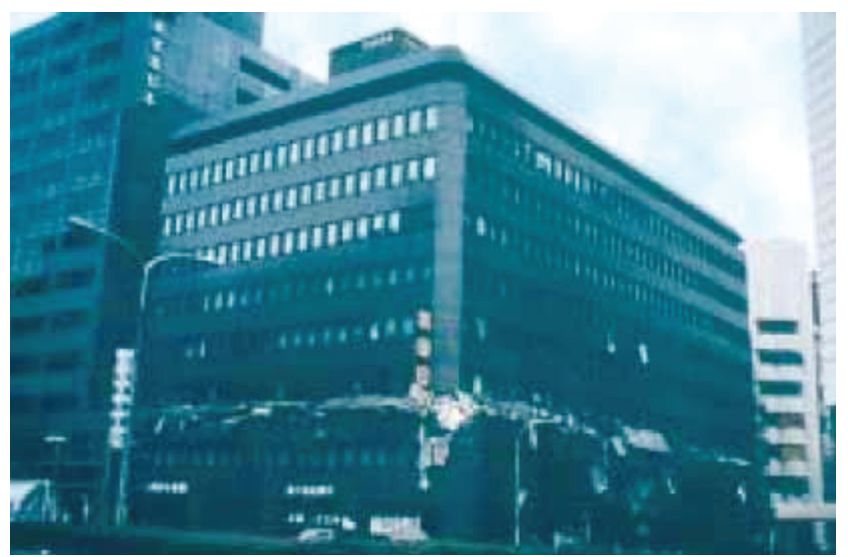

FIGURE 4. The Kobe Earthquake of 1995, the third story of the commercial building was lost and the above stories fell on it (source: Bachmann 2003). 
CASE STUDY

Some cases of soft stories on hotel buildings, government offices, shop houses and show rooms affected by the earthquake in Banda Aceh City, Padang City and Bengkulu City will be described in this part. These cases were reviewed from the results of some studies (Wilkinson et al. 2009, 2012; Maidiawati 2013; Tarigan 2007; Boen 2007a; Grundy 2010).

\section{HOTEL BUILDING}

The $M_{v} 7.6$ earthquake in West Sumatera on September 30, 2009 greatly affected the existing buildings in Padang City.

One of the most controversial cases was the collapse of Hotel Ambacang that killed 200 people. The hotel possibly suffered 'sandwich' collapse because of the soft story. In this case, the first and second floors were made of reinforced concrete material while the third floor above them was made of steel material (Figure 5). The difference of stiffness between the two materials had caused the steel structures suffered structural failure due to poor detailing, and then they fell onto the lower concrete structures.

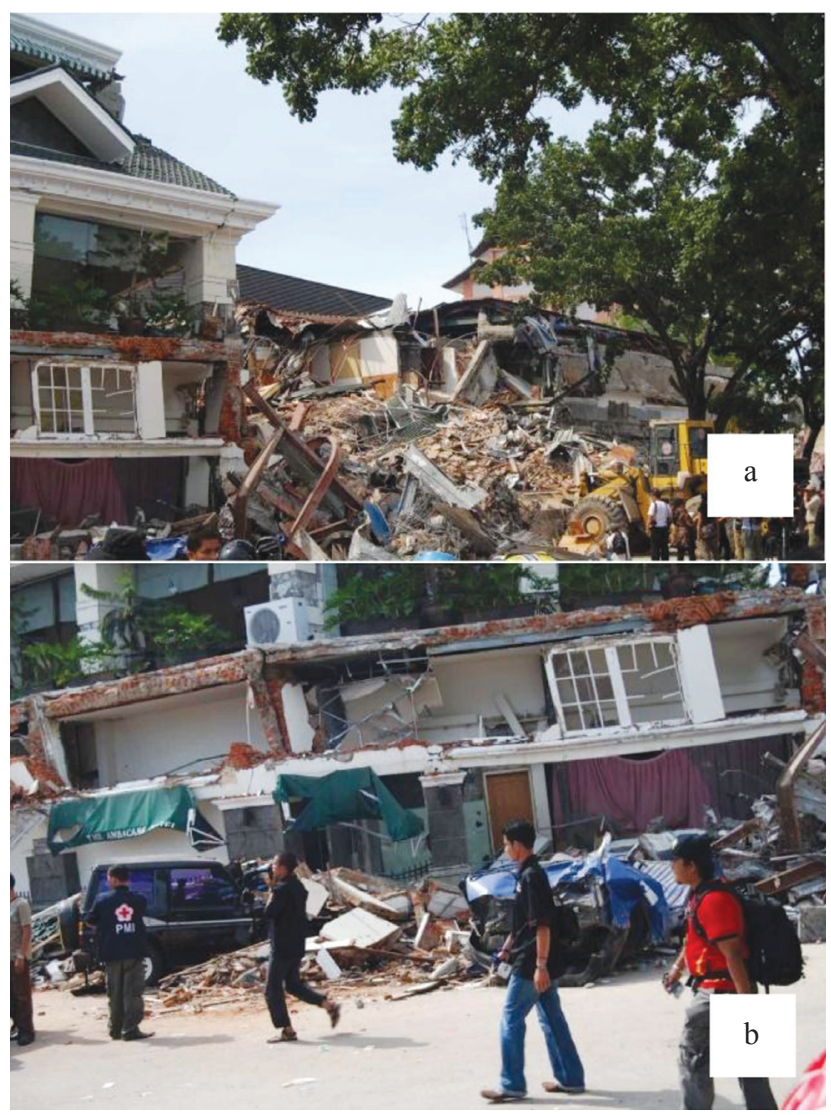

FIGURE 5. West Sumatra Earthquake in 2009, Hotel Ambacang suffered 'sandwich' collapse (source: http://xa.yimg.com/kq/ groups/17587015/808630997/name/Kerusakan+Gedung+${ }_{\text {GB }}+$ Padang.pdf).

The case above can be minimized by creating the steel structure having the same stiffness as the stiffness of the concrete structure such as adding bracing and improving the detailing quality (see Figure 6). However, this method can raise the construction cost because the steel construction is more expensive than regular steel and concrete structures.

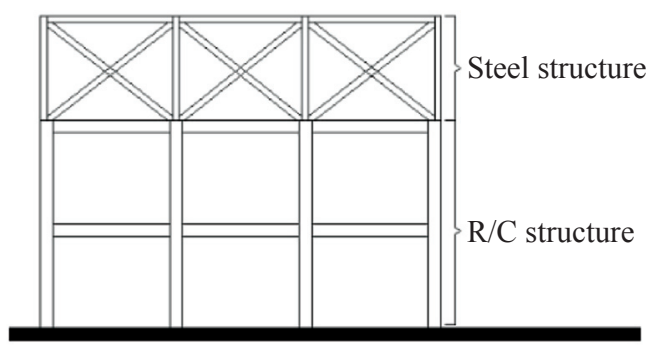

FIGURE 6 . To minimalize the stiffness difference between the steel material and the reinforced concrete material by adding bracing at the steel construction

LOCAL GOVERNMENT OFFICE BUILDING

The $M_{v} 7.6$ earthquake in West Sumatera on September 30, 2009 also caused the fall of local government offices in Padang City. One of them is the BAPPEDA Office of West Sumatera Province in Padang City.

This building consisted of three floors and made of reinforced concrete. Soft story occurred on the first floor had caused the floor to collapse while the second floor above was relatively intact (Figure 7). The shape of the building, like reversed pyramid, had caused a weak story at the first floor. In addition, the quality of concrete was also inadequate.

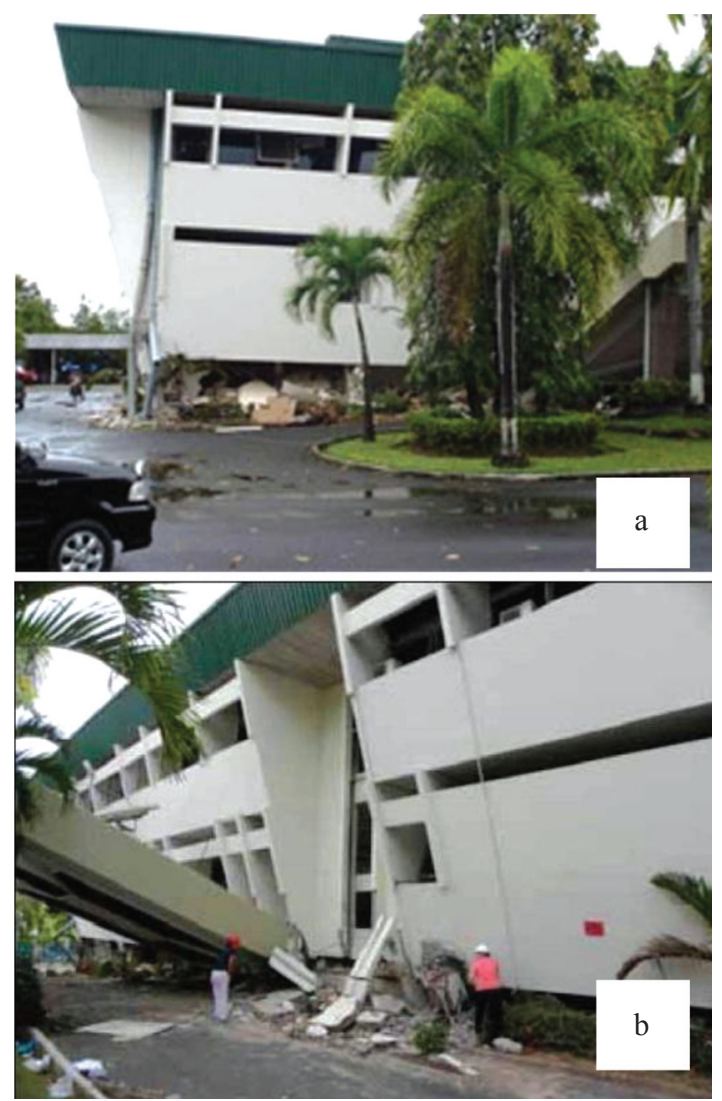

FIGURE 7. West Sumatra Earthquake in 2009. The first floor of BAPPEDA Office collapsed, but the second floor above it was relatively intact (source: Wilkinson et al. 2012). 


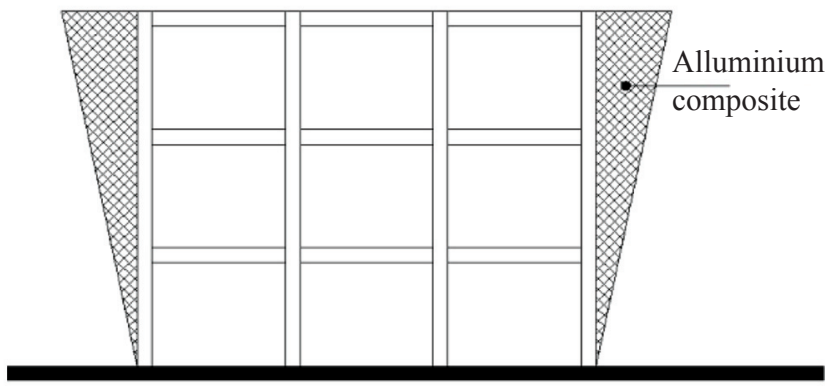

FIGURE 8 . Weak story due to reversed pyramid form can be minimalized by using flexible and light materials like aluminum composite

Weak story in the aforementioned case happened when shear capacity increased because of the use of concrete planks and other concrete elements that formed a reversed pyramid and made the shear capacity and stiffness at the first floor smaller than other floors which then led to soft story. This case can actually be solved by forming wings of the reversed pyramid from flexible and light materials such as aluminum composite (ACP), so the increase of its shear capacity and stiffness is not so significant (Figure 8).

\section{SHOPHOUSES (RUKO)}

Ruko (rumah toko)/ a shophouse is a commercial building that dominates cities in Indonesia including in earthquakeprone cities such as Banda Aceh, Bengkulu and Yogyakarta. Generally they have typical square shape where the facade has rolling gates and large windows, and shophouse units are separated by brick walls and structures made of reinforced concrete. This condition makes the shop's transversal direction more rigid than its longitudinal direction. When there is earthquake's lateral shaking, the first floor experiences a 'sway mechanism' in the direction of the longitudinal axis. Inadequate column shear capacity which is worsened by the habit of planting utility pipes in the column (Figure 10b), lack of column ductility, and poor construction have caused the residual drift (Figure 9a). If the shophouse unit is single or less, the sway mechanism on the first floor can cause 'sandwich' collapse (Figures 9b \& 10a).

The previous case can be minimized by increasing the stiffness of the first floor, that is utilized as a living space, with room's partitions from brick walls while the upper floor is utilized as commercial unit.

\section{MOTORCYCLE SHOW ROOM}

Maidiawati (2013) investigated the effect of wall infill towards the soft story in buildings. The study was conducted in two showrooms buildings experiencing the $7.6 \mathrm{M}_{\mathrm{v}}$ scale earthquake on September 2007 at Padang. Although both showrooms had the relatively same shape, they experienced different conditions. The first showroom underwent 'sandwich' collapse (Figures 11a \& 11c) while the second showroom still stood though suffering moderate damage (Figures 11b \& 11c).
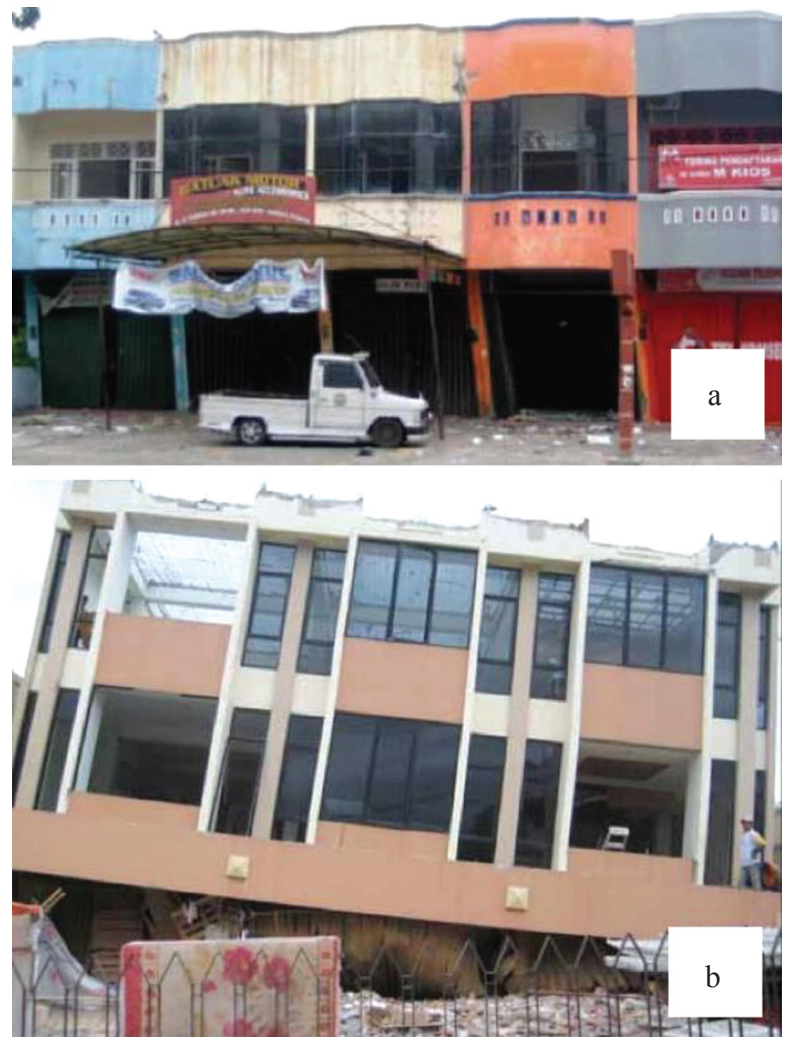

FIGURE 9. West Sumatra Earthquake in 2009, a). Ruko/ shophouses undergoing residual drift, b). The first floor of the shophouses collapsed (source: Wilkinson et al. 2012).
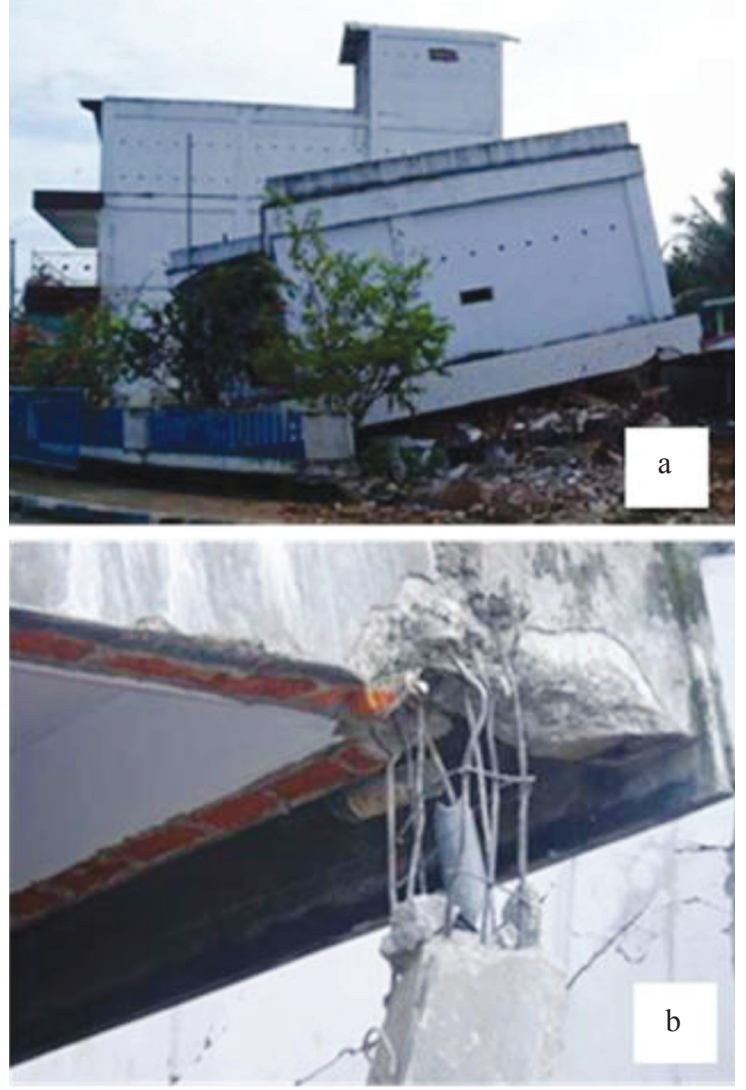

FIGURE 10. Bengkulu Earthquake in 2007, a). The collapsed shophouses, b). Planting utility pipes in the column (source: Boen 2007a). 
Maidiawati's dissertation concludes that the first showroom experienced 'sandwich' collapse condition due to the softstory on the first floor. This condition is caused by the difference of wall infill where the first floor was only $0.15 \%$ while the upper floor was more than $1 \%$. This condition then created significant stiffness difference, so when a strong earthquake occurred, the first floor was not strong enough to hold it. On the other hand, the second showroom still stood even though suffering moderate damage because the wall infill was more than $(>) 1 \%$ in every floor and its distribution among the floors was relatively even. When the strong earthquake occurred, all the floors were able to collectively withstand it.

\section{Motorcycle Show Room}
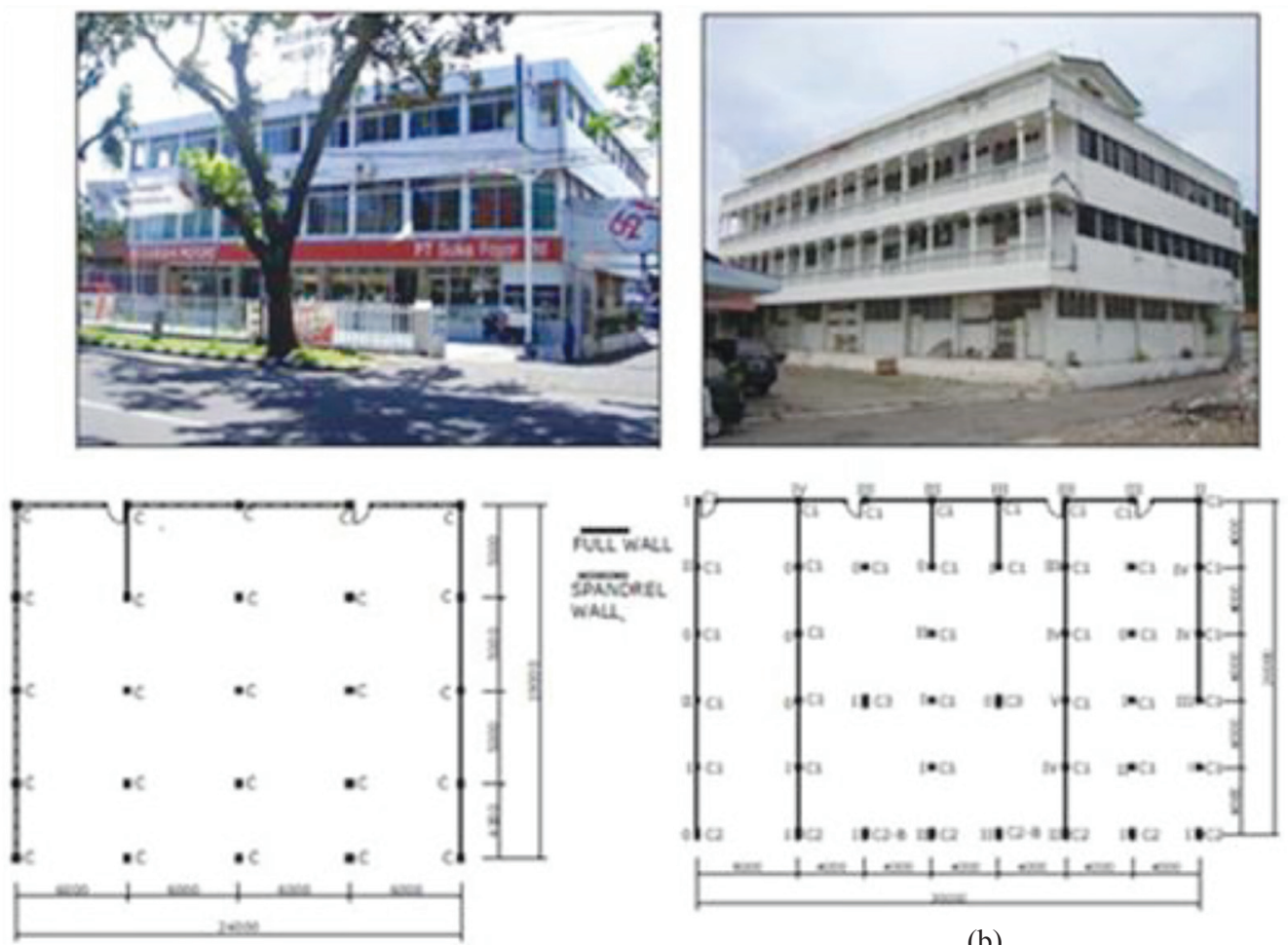

(b)

(a)

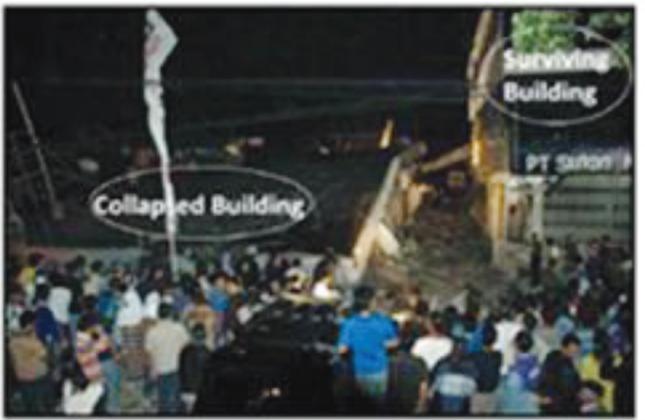

(c)

FIGURE 11. Padang Earthquake in 2007, a). The collapsed showroom, b). The surviving showroom, c). The picture of both collapsed and surviving showrooms (source: Maidiawati 2013).

The soft story that causes building collapse like the case mentioned earlier is due to several reasons ranging from the design process, the construction process, to maintenance process. In the design process, the common problem is the lack of knowledge and comprehension of the architect about an earthquake-resistant building. Therefore, the vulnerability evaluation of building design is neglected. The way to evaluate the potency of soft story in buildings and its solution concept are described below.

\section{EVALUATING SOFT STORY CONFIGURATION ON BUILDINGS}

Based on the aforementioned cases, common soft stories in Indonesia can be caused by:

1. Weak columns due to inadequate shear column capacity and/or inability to form strong column-weak beam. 
The shear capacity of columns is related to the column dimensions. For the minimum dimension columns based on the consideration of its shear strength can be evaluated by the formula (Ersoy 2013):

$$
\mathrm{A}_{\mathrm{ci}} \geq 0.0015 \sum \mathrm{A}_{\mathrm{oi}}
$$

Where,

$\mathrm{A}_{\mathrm{ci}} \quad=$ The width of the column cross section area

$\sum \mathrm{A}_{\mathrm{oi}}=$ The total area of the column load for the entire floor

$A_{c i} \geq 0.09 \mathrm{~m}^{2}(\min 30 \times 30 \mathrm{~cm})$

On the other hand, The formula below is to evaluate whether the column and beam dimensions meet the strong column-weak beam criteria (Bisch et al. 2012):

$\mathrm{W}_{\mathrm{p}}$ column $\geq 1.2 \times \mathrm{W}_{\mathrm{p}}$ beam

Where,

$\mathrm{W}=$ plastic modulus $\left(\mathrm{cm}^{3}\right.$ or $\left.\mathrm{m}^{3}\right)$

$\mathrm{W}_{\mathrm{p}}^{\mathrm{p}}=1 / 4 \times \mathrm{b} \times \mathrm{h}^{2}$

$\mathrm{b}=$ beam/column width $(\mathrm{cm}$ or $\mathrm{m})$

$\mathrm{h}=$ beam/column height $(\mathrm{cm}$ or $\mathrm{m})$

2. The occurrence of weak story or the difference in columns' shear capacity among floors.

According to FEMA 451B (FEMA 2007), weak story occurs if a building level's lateral strength is $80 \%$ less (weak story) or $65 \%$ less (extreme weak story) than the lateral strength level of the building levels above it. The formula below can be used to evaluate whether there is a weak story in the building:

$$
a_{r}=\frac{\left(\sum a_{e}\right)_{i}}{\left(\sum a_{e}\right)_{i+1}}
$$

Where, $a_{r}=$ the ratio of column width, $\left(\sum a_{\mathrm{e}}\right)_{\mathrm{i}}=$ the column width at $-\mathrm{i}$ building level and $\left(\Sigma \mathrm{a}_{\mathrm{e}}\right)_{\mathrm{i}+1}=$ the column width one level from -i building level.

TABLE 1 . The quality levels of the column width ratio $\left(a_{r}\right)$ of weak story configuration

\begin{tabular}{lccc}
\hline \multirow{2}{*}{ Source } & \multicolumn{3}{c}{ Quality levels } \\
\cline { 2 - 4 } & Good & Fair & Bad \\
\hline $\begin{array}{l}\text { Turkish Earthquake } \\
\text { Code (2007) }\end{array}$ & ar $>0.8$ & $0.65 \leq$ ar $\leq 0.8$ & ar $<0.65$ \\
& & & \\
\hline
\end{tabular}

The result from $a_{r}$ is then compared with the table 1 to know whether the weak story configuration that is formed is still tolerated/good, fair or bad.

3. The significant difference of wall infill density among floors or the irregularity configuration of out of plane offsets and in-plane discontinuity.

Evaluate the wall infill density of each floor with the formula below:

$$
d_{r}=\frac{\sum d_{i}}{\sum l_{i}}
$$

Where, $\mathrm{d}_{\mathrm{r}}=$ the wall density ratio $(\%), \Sigma \mathrm{d}_{\mathrm{i}}=$ the the brick wall width of the $-\mathrm{i}$ building level and $\Sigma \mathrm{l}_{\mathrm{i}}=$ the floor width of the $-\mathrm{i}$ building level.

TABLE 2. The quality levels of the wall density ratio $\left(d_{r}\right)$ of plane irregularity configuration

\begin{tabular}{lccc}
\hline \multirow{2}{*}{ Source } & \multicolumn{3}{c}{ Quality levels } \\
\cline { 2 - 4 } & Good & Fair & $\mathrm{Bad}$ \\
\hline Alwashali \& & $\mathrm{dr}>1.5 \%$ & $1 \% \leq \mathrm{dr} \leq 1.5 \%$ & $\mathrm{dr}<1 \%$ \\
Maeda (2012) & & $\mathrm{dr} \geq 1 \%$ & $\mathrm{dr}<1 \%$ \\
Boen et al. (2014) & - & $1 \% \leq \mathrm{dr} \leq 1.5 \%$ & $\mathrm{dr}<1 \%$ \\
Recommendation & $\mathrm{dr}>1.5 \%$ & & \\
\hline
\end{tabular}

The result of the $d_{r}$ is then compared with Table 2 to know whether the irregularity configuration of out of plane offsets and in-plane discontinuity are still tolerated/good, fair or bad.

4. Combining materials with different stiffness as the main structure of a building (Figures 12a \& 12b). In figure 12b, parts of the building made of steel can still function as a service unit and not as a living unit.

5. Inadequate structural ductility and poor construction.

To prevent these problems, strict supervision during the construction process and routine building structures maintenance are required, so the buildings appropriately function according to the initial assumption of the earthquakeresistant buildings plan.

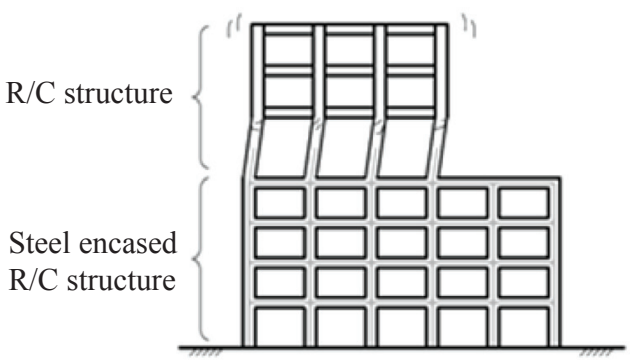

(a)

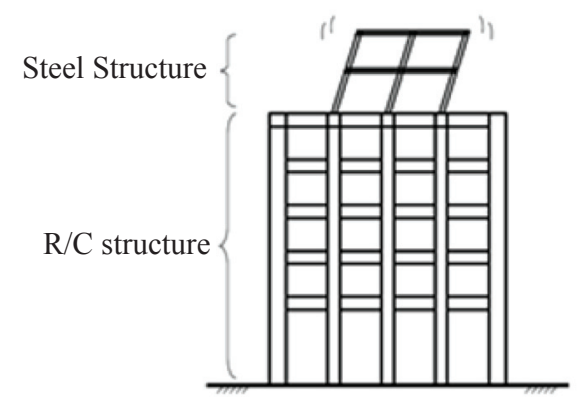

(b)

FIGURE 12. Buildings having different materials can cause soft story (source: JIA and JASO 2012) 


\section{SOLUTION CONCEPTS OF SOFT STORY CONFIGURATION IN BUILDINGS}

Soft stories should not be a barrier for architects to create innovative designs. Because in principle there is no prohibition to create irregular forms but the concern is the consequence of irregular forms uses in relation with problems of earthquake behavior toward buildings (Harmankaya and Soyluk 2012). Essentially the architects must know that their design contains a soft story and must also know the consequences of its behavior. They can avoid or maintain the design, and maintaining the design may mean finding the solution that eventually will increase the building cost.

Some practical solutions for the soft story configuration at the first floor:

1. Avoid direct contact between brick walls and columns and beams. Provide the gap between the beams and the columns with the brick walls as the walls' space to prepare for the lateral earthquake. Fill the column's gap with brittle or elastic materials to avoid the damage during the earthquake (Charleson 2008) (Figure 13).

In structural calculation, brick walls is usually assumed as non-structural, but in reality, the brick walls having density $>1 \%$ can influence the building's stiffness. Therefore, when a strong earthquake occurs, plus the existence of brick walls stiffness contribution, the building behavior towards the earthquake is often not like what the planners expect. Avoiding the direct contact between brickwalls and the structural elements is one of the ways to reduce brick walls stiffness contribution towards the building structure.

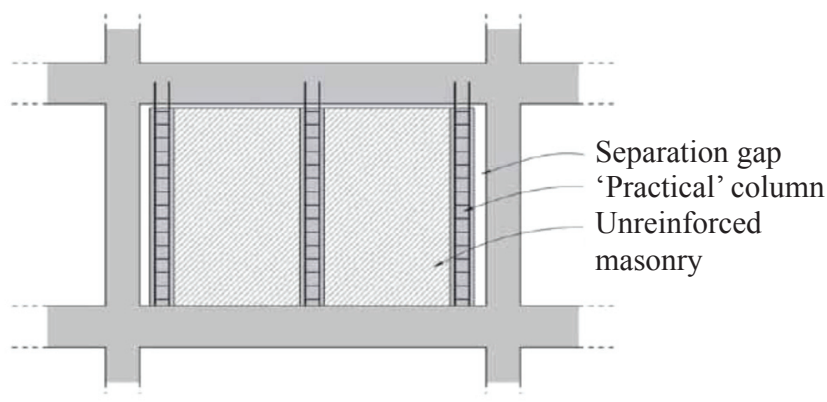

FIGURE 13. How to avoid direct contact between the brick walls and beams' and columns' main structure components (source: Charleson 2008).

2. If the building is designed with a soft story configuration at the first floor, it is recommended that the calculation of the shear capacity and the moment of the column are increased 2.5 times from the normal calculation (Narayanan, Patnala, and Kumar 2016).

The increase of the first floor's column dimension 2.5 times can influence proportion of the building facade and the first floor width (Figure 14). To reduce its effect, combine the increasing column dimension and reinforcement area.

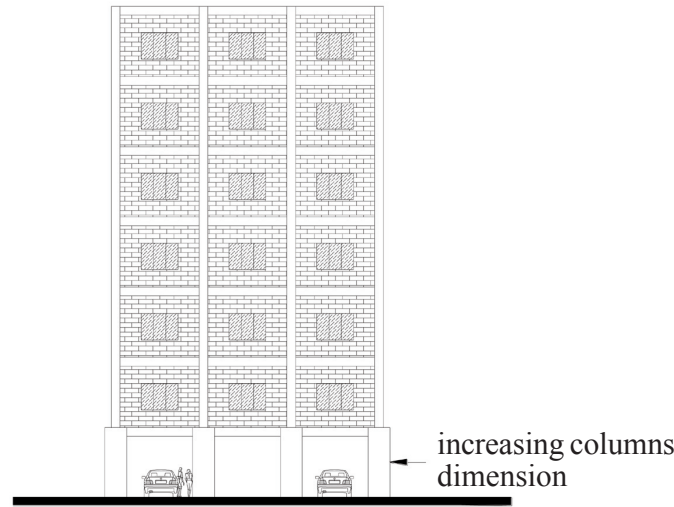

FIGURE 14. The increase of the first floor's column dimension 2.5 times can influence proportion of the building facade and the first floor width.

3. Use shear wall at the open first floor. Arrange the order, so it can still be used as a parking lot (Murty et al. 2009) (Figure 15).

The most powerful shear force is at the first floor. The use of the first floor as a parking lot significantly reduces the building's stiffness An addition of the shear wall means that it increases the stiffness of the first floor, yet its setting should not disrupt the circulation of vehicles; and the shear wall density between longitudinal axis and transversal axis should be made relatively similar (the stiffness of the longitudinal axis $\approx$ the stiffness of transversal axis).

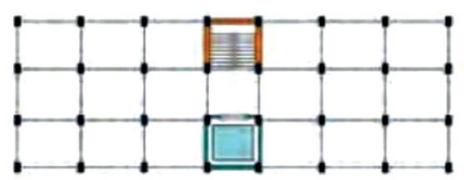

(a)

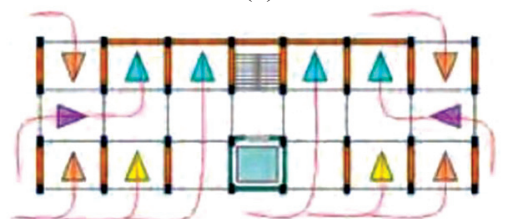

(b)

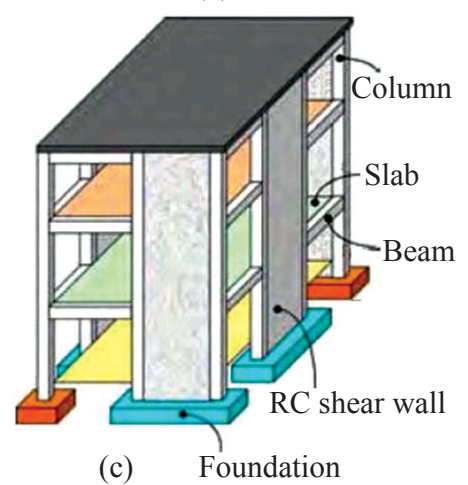

FIGURE 15. a). Buildings need a design that considers the effect of an open level on its performance. This may include: b). Providing walls on all possible panels, or c). Choosing alternative structural systems such as shear walls to carry lateral loads caused by earthquakes (source: Murty et al. 2009). 
4. Soft story at the first floor can be eliminated by adding bracing. Effective bracing placement can be conducted by a). Adding it at the first floor, b). Putting it in the center of the building, c). Installing it at all floors (Hejazi et al. 2011) (Figure 16).

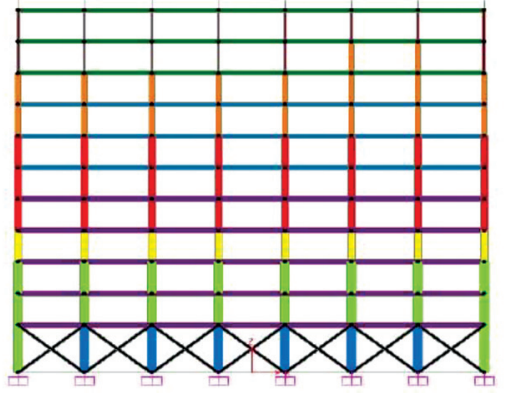

(a)

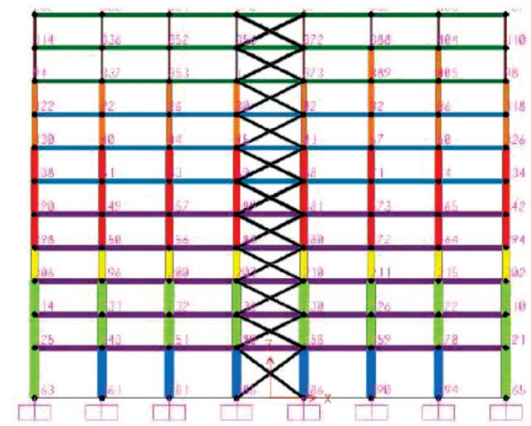

(b)

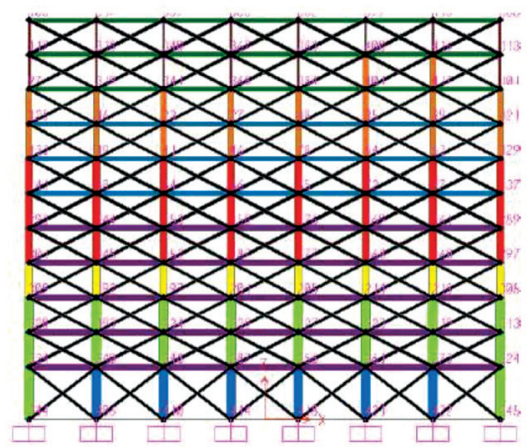

(c)

FIGURE 16. Soft stories can be eliminated with bracing: a). Adding it at the first floor, b). Putting it at the center of the building,

c). Installing it at all floors (source: Hejazi et al. 2011).

Model a and model $\mathrm{b}$ are relatively cheap, and they do not disrupt the building facade when compared with model c. Model a and model $\mathrm{b}$ can be used to increase the building stiffness though its shear force contribution is relatively small. Model c can be used to significanty increase the building stiffness and shear force capacity.

5. The use of seismic insulation comprehensively improves the building's performance that has soft stories, and it also effectively reduces the seismic demand (eg, interstory drift) at the soft story level that can cause catastrophic collapse (Pinarbasi, Konstantinidis, and Kelly 2007) (Figure 17).
The general principle of an earthquake-resistant building is that the shear force capacity of the building structure must be made bigger than the eartquake force while the principle of the isolator use, which is the reverse of the previous principle, is that the earthquake force is made smaller than the shear capacity of the building structure. In this kind of circumstances, the base isolator functions as a device to reduce the earthquake force before entering the building structure. Therefore, among the buildings that have soft stories, when strong earthquakes occur, the ones using base isolators can reduce deformation better than the ones not using base isolators (Figure 17c).

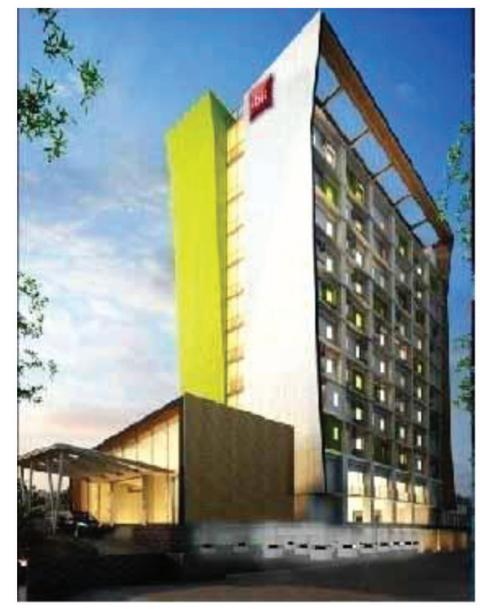

(a)

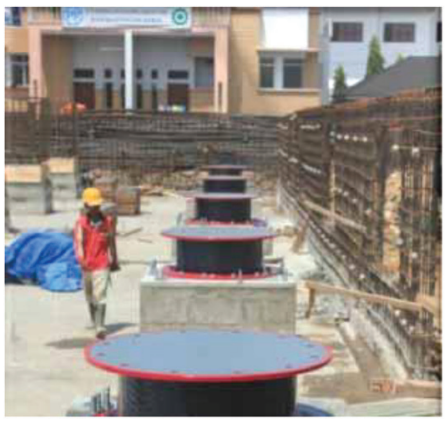

(b)

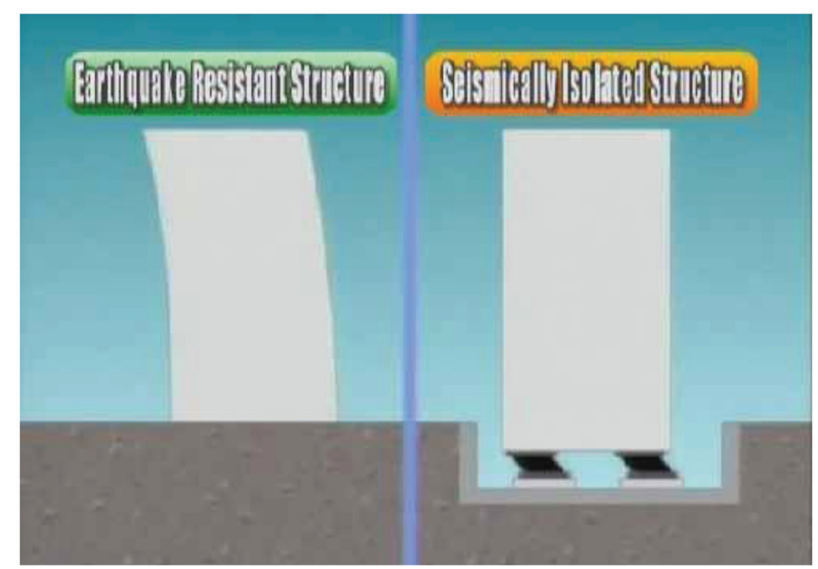

(c)

FIGURE 17. (a). Hotel Ibis Padang, (b). Installation of base isolator, (c). The working mechanism of the base isolator (source: Suardi 2013). 
To make the evaluation of the soft story at a building and to conduct its application for the solution easier, see the flowchart in the Figure 18.

\section{CONCLUSION}

Indonesia is an area prone to earthquakes. From all the earthquakes that have occurred in Indonesia, soft story is the most frequent case that triggers 'sandwich' collapse. The causes of the soft story at the first floor are: inadequate shear column capacity, the occurrence of a weak story, the significant difference in wall infill density among floors, the use of materials having different stiffness in the main structure, and structure ductility and poor construction.

Planning earthquake resistant buildings is the responsibility of architects and structure experts. To reduce the potency of soft story at the first floor, several things can be done by architects in the designing process such as:
To reduce the potency of soft story, several things can be done by architects in designing processes such as: avoiding direct contact between brick walls and columns and beams, increasing columns shear capacity 2.5 times from the normal calculation, using the shear walls on the first floor, installing bracings, and using seismic insulations.

Good collaboration between architects and structural experts is expected to create earthquake resistant buildings. Such buildings will eventually reduce the potential of building collapse during earthquake that can cause many casualties, particularly in Indonesia.

\section{ACKNOWLEDGEMENT}

This research is fully supported by DRPM Ditjen Penguatan Risbang. The authors fully acknowledged Ministry of RISTEKDIKTI and University of Sriwijaya for the approved fund which makes this important research viable and effective.

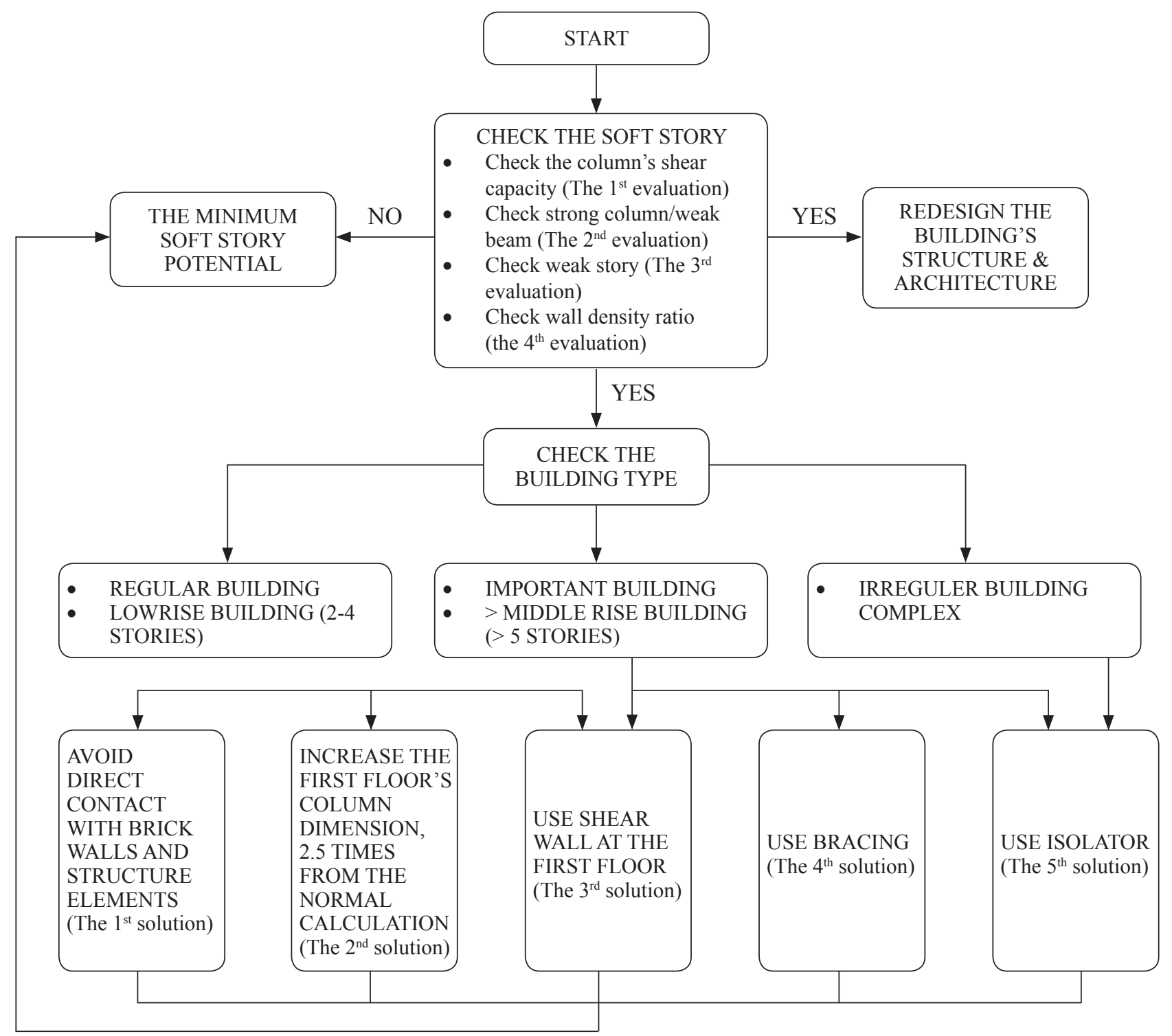

FIGURE 18. The flowchart of the soft story evaluation on a building and its application for the solution 
REFERENCES

Al Washali, Hamood \& Masaki Maeda. 2012. Study of Seismic Evaluation Methods of RC Buildings with Masonry Infill Walls; A Case Study of Building in Jordan. International Symposium on Earthquake Engineering, JAEE, Vol. 1, edited by Japan Association for Earthquake Engineering (JAEE): 497-506.

Arnold, C. 2001. Architectural Considerations. The Seismic Design Handbook, edited by Farzad Naeim. Boston, MA: Springer US.

Bachmann, Hugo. 2003. Seismic Conceptual Design of Buildings - Basic Principles for Engineers, Architects, Building Owners, and Authorities. Swiss: Vertrieb Publikationen.

Bisch, P., Carvalho, E., Degee, H., Fajfar, P., Fardis, M., Franchin, P., Kreslin, M., Pecker, A., Pinto, P., Plumier, A., Somja, H. \& Tsionis, G. 2012. Eurocode 8: Seismic Design of Buildings Worked Examples. Luxembourg: Publications Office of the European Union.

Boen, T. 2007a. Bengkulu \& West Sumatra Earthquakes, September 12, 2007, Structural Damage Report.

Boen, T. 2007b. West Sumatra Earthquake, 6 March 2007, Structural Damage Report. Konstruksi Tahan Gempa Indonesia, edited by HAKI, 1-30. Jakarta: HAKI.

Boen, T., Anand, S. A. \& Yuji, I. 2014. Guidelines for Earthquake Resistant Non-Engineered Construction. UNESCO.

Boen, T. 2006. The Yogya Earthquake 27 May 2006, Structural Damage Report.

Charleson, A. 2008. Seismic Design for Architects. New York: Architectural Press.

Earthquake Research Departement. 2007. Turkish Earthquake Code (TEC). General Directorate of Minister Affairs.

Ersoy, U. 2013. A Simple Approach for Preliminary Design of Reinforced Concrete Structures to Be Built in Seismic Regions. Teknik Dergi 24(4): 6559-74.

FEMA. 2007. NEHRP Recommended Provisions for New Buildings and Other Structures: Training and Instructional Materials-FEMA 451B. Washington DC: Federal Emergency Management Agency (FEMA).

Grundy, Paul. 2010. The Padang Earthquake 2009 - Lessons and Recovery. In Australian Earthquake Engineering Society 2010 Conference.

Harmankaya, Z. Y. \& Soyluk, A. 2012. Architectural Design of Iregular Buildings in Turkey. International Journal of Civil \& Environmental Engineering IJCEE-IJENS 12(1): 42-48.

Hejazi, F., Jilani, S., Noorzaei, J. Chieng, C.Y., Jaafar, M.S. \& Abang Ali, A.A. 2011. Effect of Soft Story on Structural Response of High Rise Buildings. In IOP Conference Series: Materials Science and Engineering 17(1): 12034.

Hoedajanto, D. \& Riyansyah, M. 2015. Bangunan Tahan Gempa Dan Tanggung Jawab Legal Praktisi Konstruksi Indonesia. In Challenges in the Future, Jakarta: HAKI, $1-10$.

JIA \& JASO, eds. 2012. Earthquake-Resistant Building Design for Architects. Japan: Takhesi Goto.
Mediawati. 2013. Modeling of Brick Masonry Infill for Seismic Performance Evaluation of RC Frame Buildings. Doctoral Thesis Toyohashi: Toyohashi University of Technology.

Mezzi, M. 2006. Enhancing the Seismic Performance of Existing 'Pilotis' Configurations. In IABSE Symposium Report 92(3): 10-17.

Murty, C. V. R., Brazev, S., Faison, H., Comartin, C. D. \& Irfanoglu, A. 2009. Perilaku Bangunan Struktur Rangka Beton Bertulang dengan Dinding Pengisi dari Bata Terhadap Gempa. Oakland: EERI.

Subramanian, N., Neelima, P. \& Kumar, R. P. 2016. Effect of Weak and Soft Storeys on Seismic Performance of Reinforced Concrete Frames with Unreinforced Brick Infills, The Indian Concrete Journal 90: 46-52.

Mark, P., Maskrey, A., Ruiz, P. \& Hall, L. 2004. Reducing Disaster Risk, A Challenge for Development. New York.

Pinarbasi, S., Konstantinidis, D. \& Kelly, J. M. 2007. Seimic Isolation for Soft Storey Buildings. In 10th World Conference on Seismic Isolation, Energy Dissipation and Active Vibrations Control of Structures, Istanbul, Turkey.

Rashid, M. 2016. A Decade after the Tsunami: Preliminary Exploration Deposit Layer of Sediment at Coast Area of Kedah, Malaysia. Jurnal Kejuruteraan 28: 1-8.

Riza, M. M. 2013. Bentuk Keruntuhan Bangunan Saat Gempa. http:/www.perencanaanstruktur. com/2010/10/ bentuk-keruntuhan-bangunan-saat-gempa.html[2013]

Suardi, E. 2013. Rubber Bearing Isolator Sebagai Sistem Penahan Gempa pada Bangunan Hotel Ibis Padang. Jakarta: PT. PP (Persero) Tbk.

Tarigan, J. 2007. Kajian Struktur Bangunan di Kota Medan Terhadap Gaya Gempa di Masa yang Akan Datang.

Wilkinson, S. M., Alarcon, J. E., Mulyani, R., Whittle, J. \& Chian, S. C. 2009. The Padang Sumatra-Indonesia Earthquake of 30 September 2009. A Field Report by EEFIT.

Wilkinson, S. M., Alarcon, J. E., Mulyani, R., Whittle, J. \& Chian, S. C. 2012. Observations of Damage to Buildings from MW 7.6 Padang Earthquake of 30 September 2009. Natural Hazards 63(2): 521-47.

*Livian Teddy, Gagoek Hardiman

Doctoral Program of Architecture and Urban Science

Diponegoro University, Semarang, Indonesia.

Nuroji, Sri Tudjono

Doctoral Program of Civil Engineering

Diponegoro University, Semarang, Indonesia.

*Corresponding author; email: livianteddy@gmail.com

Received date: $8^{\text {th }}$ February 2018

Accepted date: $17^{\text {th }}$ May 2018

Online First date: $1^{\text {st }}$ September 2018

Published date: $31^{\text {st }}$ October 2018 